\title{
Pharyngeal rhinosporidiosis
}

\author{
Aswin Chandran, ${ }^{1}$ Pirabu Sakthivel 다, ${ }^{1}$ Rakesh Kumar, ${ }^{1}$ Madhu Rajeshwari ${ }^{2}$
}

${ }^{1}$ ENT and Head and Neck Surgery, All India Institute of Medical Sciences, New Delhi, Delhi, India

${ }^{2}$ Pathology, All India Institute of Medical Sciences, New Delhi, Delhi, India

\section{Correspondence to} Dr Pirabu Sakthivel; pirabusakthivel@gmail.com

Accepted 16 May 2020

\section{DESCRIPTION}

A 38-year-old man presented to our hospital with complaints of a foreign body sensation in throat and frequent spitting of blood-tinged saliva for 6 months duration. On examination, a reddish pedunculated mass studded with whitish spots was seen hanging in oropharynx just behind uvula (figure 1A). On nasal endoscopy, mass was seen attached along the under surface of left inferior turbinate, which bled on contact. The patient also gave history of taking frequent baths in local ponds. After a clinical diagnosis of rhinosporidiosis, he underwent complete excision of the mass after bipolar cauterisation of the base under local anaesthesia (figure 1B). Postoperative histopathology revealed multiple sporangia in various stages of maturation with dense inflammation suggestive of rhinosporidiosis (figure 1C). At 1-year follow-up, the patient had no recurrences.

Rhinosporidiosis is a chronic granulomatous disease caused by Rhinosporidium seeberi, which are mostly parasites of fish, in the class Mesomycetozoa. ${ }^{1}$ Disease is endemic to India and other Southeast Asian countries and is transmitted to people taking bath in contaminated water bodies like stagnant ponds. ${ }^{1}$ Primarily a disease of nose which usually presents as a reddish nasal mass that bleeds on touch, it can also affect the mucous membrane of nasopharynx, oropharynx, conjunctiva, rectum and external genitalia. Pharyngeal rhinosporidiosis is a rare disease, which can be an extension of nasal or nasopharyngeal lesion or an isolated lesion with very few reported cases in literature. ${ }^{2}$ It can present as dysphagia, nasal or oral bleeding and even respiratory distress in case of complete oropharyngeal involvement. Pharyngeal rhinosporidiosis must be differentiated from any bleeding nasal mass with oropharyngeal extension like angiomatous polyp, rhinoscleroma, angiofibroma, inverted papilloma and even malignancy. The diagnosis is clinical by its usual classical 'strawberry appearance' (reddish mass studded with white spots of sporangiospores) and can be confirmed by

Limited 2020. No commercia re-use. See rights and permissions. Published by BMJ.

To cite: Chandran $A$

Sakthivel P, Kumar R,

et al. BMJ Case Rep

2020;13:e236404

doi:10.1136/bcr-2020

236404

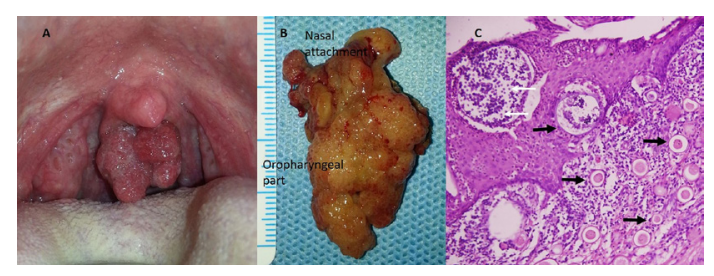

Figure 1 Rhinosporidiosis. Clinical image showing a 'strawberry mass' just behind the uvula (A). Excised specimen (B). Histopathology showing multiple spores in different stages of maturation (black arrows) along with sporangiospores (white arrows) suggestive of rhinosporidiosis $(H \& E \times 40)(C)$.

\section{Patient's perspective}

I was having foreign body sensation in the throat which was associated with it occasional spitting of blood stained sputum for 6 months. I consulted hospital for this complaints and doctor told me that I am having a mass in the throat probably coming from nose and which require surgical removal. They also told me that the mass is because of some parasitic infection, which I would have acquired through bathing in a contaminated pool that I used to do in the past. My surgery was uneventful and I am symptom free since last 1 year although doctors suggested that the infection may recur in the future and also warned me regarding taking bath in contaminated ponds.

\section{Learning points}

- Rhinosporidiosis is a chronic granulomatous disease of the nose, which usually presents as a fleshy bleeding nasal mass but can also involve nasopharynx, oropharynx, conjunctiva and facial skin.

- Surgical excision is the treatment of choice, and diagnosis is confirmed by histopathology of excised tissue.

- Rhinosporidiosis has a high recurrence rate requiring multiple surgeries, so long-term follow-up is mandatory.

histopathology of excised specimen, which reveals typical sporangia and spores in the affected tissue. The treatment of choice is complete surgical excision along with cauterisation of base to prevent the recurrence as diathermy abate the endospore spilled in the adjacent mucosa. Although no adequate medical therapy exists, dapsone that interferes with maturation of spores has been used in preventing the recurrence. ${ }^{3}$ Rhinosporidiosis has a high recurrence rate requiring multiple surgeries resulting in increased morbidity. ${ }^{4}$

Contributors AC, PS, RK and MR were involved in the clinical care of the patient, literature review and manuscript preparation. All authors read and approved the final manuscript.

Funding The authors have not declared a specific grant for this research from any funding agency in the public, commercial or not-for-profit sectors.

Competing interests None declared.

Patient consent for publication Obtained.

Provenance and peer review Not commissioned; externally peer reviewed.

ORCID iD

Pirabu Sakthivel http://orcid.org/0000-0002-6941-9892 
Images in...

\section{REFERENCES}

1 Herr RA, Ajello L, Taylor JW, et al. Phylogenetic analysis of Rhinosporidium seeberi's $18 \mathrm{~S}$ small-subunit ribosomal DNA groups this pathogen among members of the protoctistan Mesomycetozoa clade. J Clin Microbiol

$1999 ; 37: 2750-4$
2 Halve A, Shedge S, Jain V, et al. Pharyngeal rhinosporidiosis: a case report. Journal of Evolution of Med and Dent Sci 2014:3:6605-9.

3 Arseculeratne SN. Chemotherapy of rhinosporidiosis: a review. Journal of Infectious Disease and Antimicrobial Agent 2009;26:21-7.

4 Kanodia A, Sakthivel P, Singh CA, et al. Strawberry nose and rhinosporidiosis. QJM 2020;113:64-5.

Copyright 2020 BMJ Publishing Group. All rights reserved. For permission to reuse any of this content visit https://www.bmj.com/company/products-services/rights-and-licensing/permissions/

BMJ Case Report Fellows may re-use this article for personal use and teaching without any further permission.

Become a Fellow of BMJ Case Reports today and you can:

- Submit as many cases as you like

- Enjoy fast sympathetic peer review and rapid publication of accepted articles

Access all the published articles

Re-use any of the published material for personal use and teaching without further permission

Customer Service

If you have any further queries about your subscription, please contact our customer services team on +44 (0) 2071111105 or via email at support@bmj.com.

Visit casereports.bmj.com for more articles like this and to become a Fellow 